\title{
A NOVEL MECHANISM CONTROLLING THE GROWTH OF HEMOSTATIC THROMBI
}

\author{
V. K. LISHKO, I. S. YERMOLENKO, N. P. PODOLNIKOVA, T. P. UGAROVA
}

School of Life Sciences, Arizona State University, Tempe, AZ USA

Current knowledge of the mechanisms of blood coagulation does not provide an answer to one pivotal question: why is, in contrast to a pathological thrombus, the growth of normal hemostatic clot after blood vessel injury suddenly terminated? In the present paper, we summarize the results of our investigations that give an answer to this question. We show that the surface of fibrin clot in the circulation is coated with a thin metastable layer of fibrinogen which is not able to support adhesion of blood cells. Consequently, platelets and leukocytes, the cells expressing adhesive integrins, are incapable of consolidating their grip on the surface and washed away by blood flow, thereby preventing the thrombus propagation. The cells that escaped this fibrinogen shield and reached a solid fibrin matrix use an additional mechanism - the ability to activate plasminogen bound either to the surface of cells or to fibrin. Plasmin formed at the interface between the cells and the clot locally degrades fibrin resulting in the fragmentation of the surface rendering it unstable, non-adhesive and therefore non-thrombogenic. Thus, the growth of hemostatic thrombus is halted by two mechanisms, fibrinogen- and plasminogen-dependent, both of which are based on the same principle - the generation of the mechanically unstable, non-adhesive surface.

Ke y words: fibrinogen, fibrin, plasminogen, plasmin, plasminogen activation, mechanical vascular injury.

$\mathrm{T}$ he formation of a haemostatic thrombus during blood vessel injury is a highly regulated event. The process ensures that a blood clot is sufficiently strong to seal the breach and prevent the loss of blood, however does not cause vessel occlusion and thrombosis. Hemostasis and thrombosis are related events, but the former is a normal protection from bleeding after injury, while the latter is a consequence of a disease. And the structure of the plug at the site of injury and pathological thrombus is strikingly different. The diagram (Fig. 1) shows a composition of blood clot. It is formed mainly from aggregated platelets and fibrin. The process starts with accumulation of platelets at the site of injury. Tissue factor is expressed immediately followed by activation of thrombin and fibrin formation. In the end of the process, the surface of the thrombus is covered with a fibrin cap, the accumulation of fibrin reaches a plateau and the growth of the entire thrombus is stabilized [1-3]. Using antibody against fibrin and platelets we could see (Fig. 2) the formation of fibrin layer which shields the platelet plug.

While this hemostatic process has been extensively studied for more than a century, many questions remain. The main unanswered problem is how the growth of hemostatic thrombus in a high-pressure circulatory system is contained and what mechanisms limit its propagation. It is well known that after the fibrin clot covers the platelet plug, only very few platelets and leukocytes stick to its surface [4-7]. This finding is puzzling in light of the fact that fibrin is highly adhesive for platelets, at least in the experiments performed in vitro. Regardless, it seems obvious that fibrin deposited on the surface of haemostatic clots in vivo must not be adhesive because if not curtailed, uncontrollable platelet adhesion can readily lead to their activation and thrombus propagation. $\mathrm{Ob}-$ viously, continuous thrombus growth would lead to pathological thrombosis. Likewise, adhesion of leukocytes, which are known to contain potent fibrinolytic enzymes, must be regulated to allow early hemostasis to proceed unchallenged until the growth and stability of the blood clot is established. Therefore, a proper balance between adhesive and anti-adhesive mechanisms operating on the surface of fibrin clots in circulation may play an important role in the control of thrombus formation, stability, and timely dissolution. In spite of the obviousness of this idea, the fact that the surface of fibrin clots in circulation is not adhesive for blood cells is unappreciated.

Another unresolved question is why the antiadhesive mechanisms that effectively halt the growth of normal hemostatic thrombi fail in pathological situations. Hemostasis and thrombosis are related events in that they both trigger similar molecular and cellular mechanisms; yet, thrombotic episodes often lead to an uncontrollable growth of blood clots resulting in vascular occlusion. Furthermore, not only their outcomes vary, but it is uncertain why the morphology of hemostatic and 


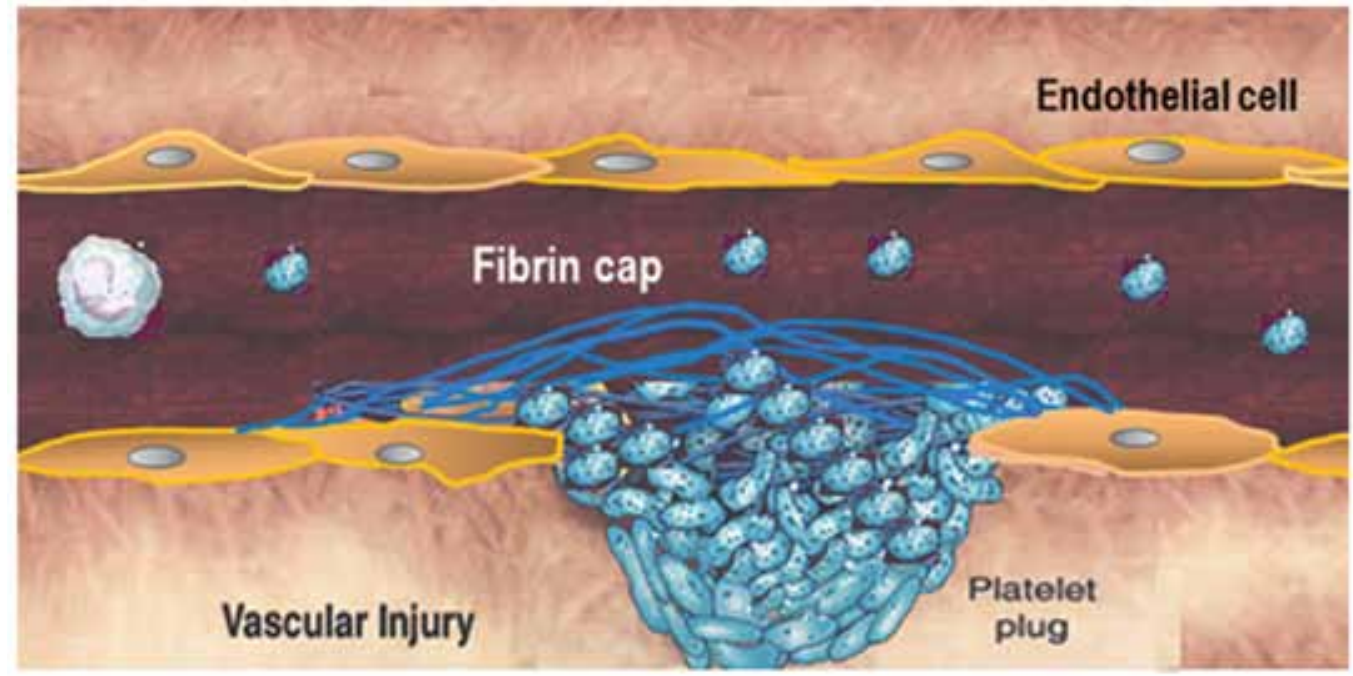

Fig. 1. Composition of normal hemostatic thrombus which is formed in response to vascular injury

pathologic thrombi is strikingly different. It is well known that clots formed in the arterial diseases and in deep vein thrombosis invariably manifest a laminated structure with alternating layers of aggregated platelets and fibrin enmeshed with erythrocytes (so called, lines of Zahn, Fig. 3).

In this paper, we review our recent findings that support the idea for the existence of a universal mechanism that limits uncontrolled expansion of hemostatic clots in circulation and may be responsible for restraining their premature lysis. We propose that a factor which determines the nonthrombogenic nature of blood clots and also guards their integrity in early hemostasis is the limited adhesiveness of their surface. As such, this mechanism represents a new aspect of hemostasis.

The discovery was born from a very simple cell adhesion experiment in which fibrinogen is used as a ligand for cellular integrins. In these assays, cells are added to the wells coated with fibrinogen or other proteins. After some time, cells are washed away and adherent cells are counted. We observed that when fibrinogen is adsorbed on the surface at increasing concentrations, adhesion of platelets and leukocytes exhibits an unusual peak-like behavior (Fig. 4) [8]. Cell adhesion is maximal at low concentrations of fibrinogen and then sharply declines as more fibrinogen is adsorbed on the surface. This behavior is counter-intuitive because, typically, the increase in the density of adsorbed ligands results in the increased adhesion. Yet, fibrinogen adsorbed at high density is virtually nonadhesive. This abnormal behavior is exhibited only by fibrinogen, but not by other plasma proteins. For example, adhesion of cells to immobilized fibronectin exhibits a normal dosedependent pattern (Fig. 4).

Based on the initial analyses of the "adhesion peak", we hypothesized that fibrinogen adsorbed at low concentrations is attached directly to the solid surface. Therefore, cells that engage such molecules would adhere strongly. We further hypothesized that fibrinogen adsorbed at higher concentrations would bind to the molecules that have already been immobilized on the surface forming a second, more flexible layer. Thus, these cells would
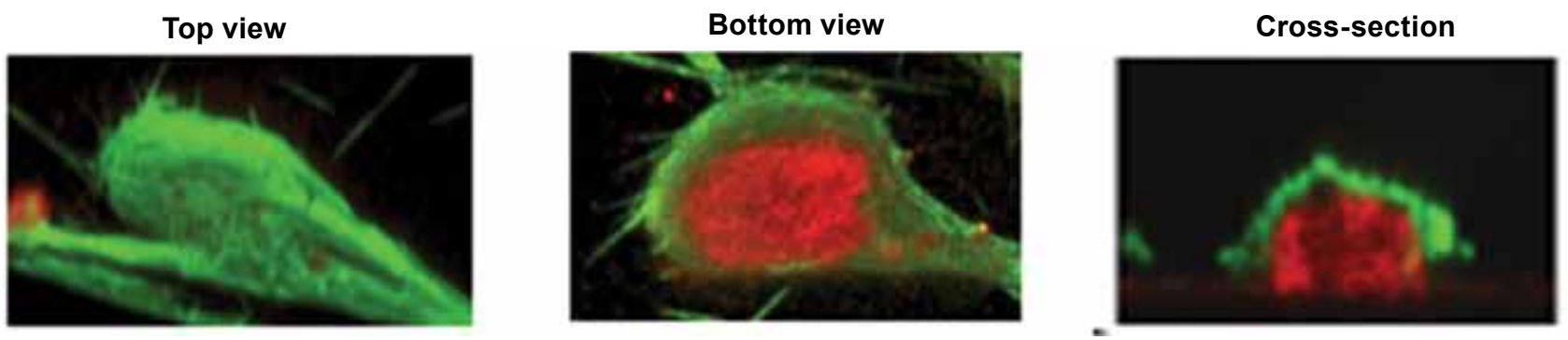

Fig. 2. Formation of fibrin cap on the surface of thrombus. Platelet plug was formed on collagen by plasma under flow. The clot was labeled with fluorescent antibody against platelets (red) and against fibrin (green) 


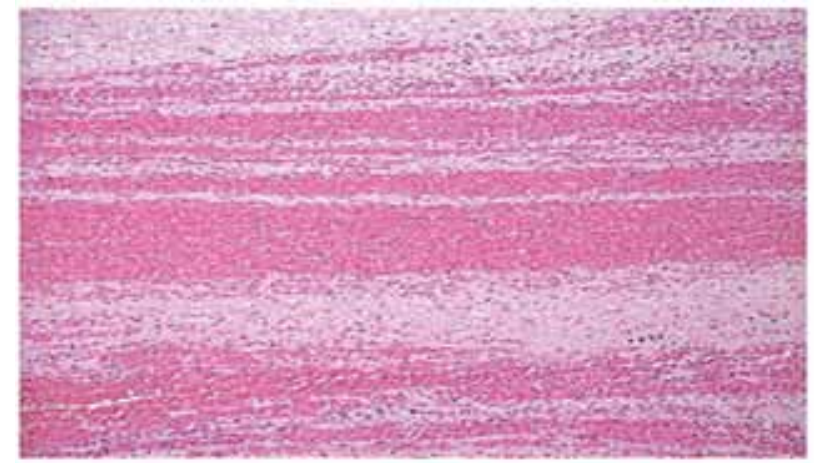

Fig. 3. The structure of arterial thrombus consists of alternate layers of aggregated platelets (white) and plasma clot with captured red blood cells (red). From http://library.med.utah.edu

adhere to the adhesive layer consisting of loosely bound fibrinogen molecules and be less capable of consolidating their grip on this "fake" substrate, and detach when flow is applied.

Since fibrinogen molecules do not selfassociate in solution, there should be a trigger that initiates this process. Indeed, fibrinogen adsorbed on the surface undergoes conformational changes and acquires the properties of fibrin [9-12]. Hence, upon its immobilization, unfolded fibrinogen may generate the fibrinogen-binding activity. To characterize fibrinogen interactions, we determined the dissociation constants of its complexes using surface plasmon resonance (SPR). Intact fibrinogen was coupled to the chip, and the SPR profiles across a range of fibrinogen concentrations flowed over the protein surfaces were examined. No binding of soluble fibrinogen to intact fibrinogen was detected. However, when intact fibrinogen on the chip was treated with SDS or urea, it formed a complex with intact soluble fibrinogen with a $K_{\mathrm{D}}$ of $2.1 \mu \mathrm{M}$ which was similar to that obtained for the interaction of fibrinogen and fibrin $(1.47 \mu \mathrm{M})$ [8]. Thus, an initial contact of fibrinogen with various surfaces may initiate the process of its self-assembly.

The surface of blood clots in circulation is continuously exposed to high concentrations of fibrinogen. It is well established that fibrinogen forms complexes with fibrin and can self-associate without thrombin activation, forming aggregates. Therefore, by virtue of its ability to interact with fibrin clots, fibrinogen can be deposited on their surface. We found that similar to adsorption on hard surfaces, fibrinogen deposited on the surface of fibrin clots imparts them antiadhesive properties [8, 13]. Notably, when clots are pretreated with soluble fibrinogen, it accumulates in a thin superficial layer of the clot (Fig. 5A) [14]. Fig. 5B illustrates adhesion of leukocytes to fibrin clot under flow. In this experiment, cells flow through a capillary made in the fibrin gel. While a massive accumulation of adherent cells is observed in the buffer, the presence of a physiological concentration of fibrinogen strongly reduces adhesion. Taken together, these experiments led us to the idea that adsorption of fibrinogen somehow modifies the surfaces rendering them nonadhesive.

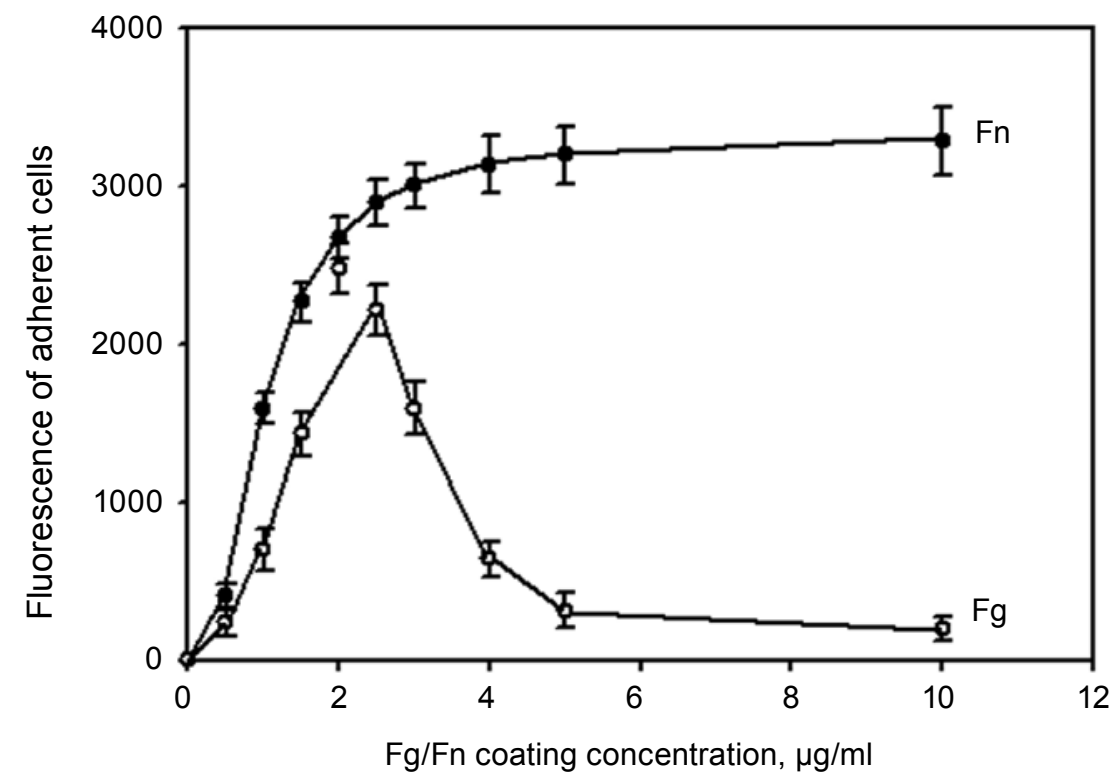

Fig. 4. Adhesion of monocytic cells to fibrinogen and to fibronectin. Effect of protein coating concentration on cell adhesion 
$A$

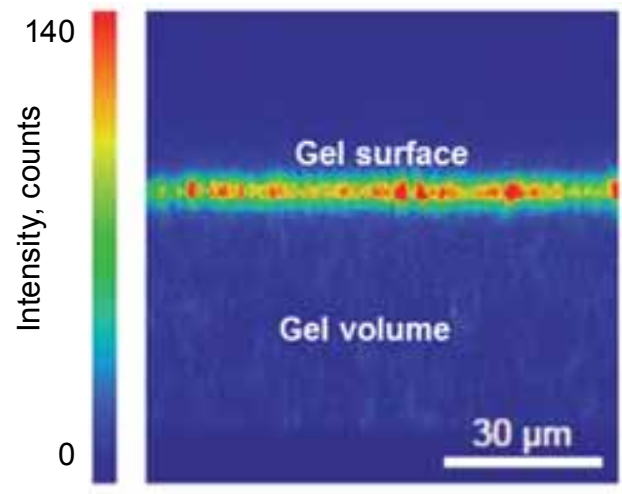

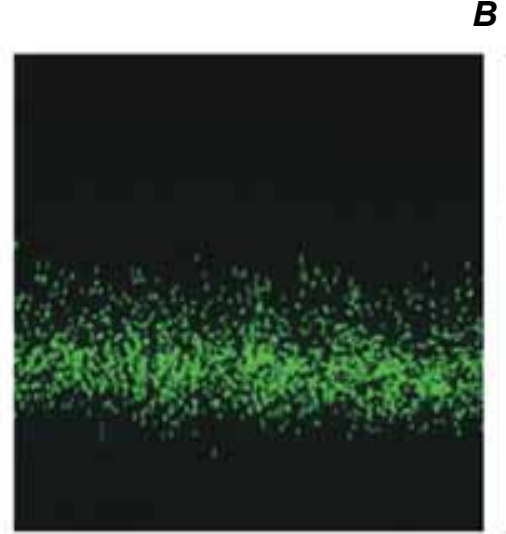

Buffer

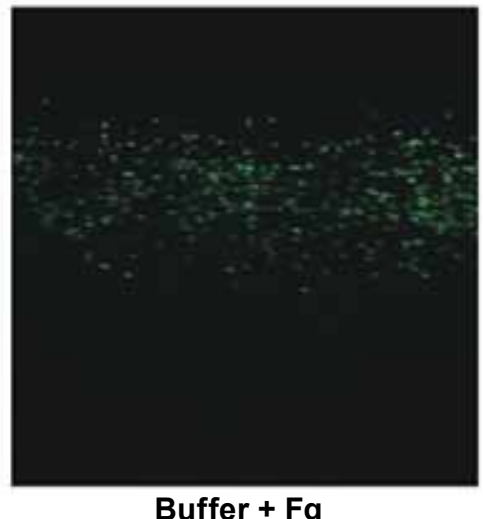

Fig. 5. Accumulation of fibrinogen on the surface of fibrin. Confocal image of fibrin gel incubated with the solution of fluorescent labeled (Alexa-488) fibrinogen (A). Effect of soluble fibrinogen on adhesion of monocytic cells to fibrin under flow conditions. Suspension of calcein-labeled U937 cells with or without fibrinogen $(2.0 \mathrm{mg} / \mathrm{ml})$ were perfused through capillary casted in fibrin gel (B)

Although attractive, the idea that immobilization of fibrinogen on the surfaces results in its self-assembly and the formation of the layer required independent experimental evidence. We used atomic force microscopy (AFM) to demonstrate the ability of fibrinogen to form a multilayer matrix and measured the adhesiveness of this structure. Visualization of fibrinogen deposited on the surface showed that as the concentration of fibrinogen increases, its adsorption changes from a monolayer, in which the molecules are clearly discernible and attached directly to the surface, then to the bilayer and then to the material which has an appearance of a thick soft matrix (Fig. 6) [15]. Using nanolithography, which is one of the capabilities of AFM that allows us to scratch the deposited fibrinogen material and determine its thickness we were able to calculate the number of layers in the fibrinogen matrix. Given that a single fibrinogen molecule has a height of $1.2 \mathrm{~nm}$ [16] and the matrix that is deposited at high concentrations has a height of about 7-8 nm, we conclude that the matrix contains approximately 7 layers.

With the data indicating that adsorption of fibrinogen on various surfaces indeed results in its deposition as a multilayer matrix, the question was why the assembled multilayer is much less adhesive than the monolayer. Using AFM-based force spectroscopy, we found that there is a correlation between the growth of the fibrinogen matrix and its adhesiveness. As soon as fibrinogen is deposited in the form of bilayer, its adhesiveness sharply declines (Fig. 7A) [15]. The subsequent increase in the number of layers results only in an incremental decrease in adhesion.
Why does fibrinogen multilayer limit cell attachment? Fig. 7B and 7C show how strikingly different is the morphology of monocytic cells on the fibrinogen monolayer and multilayer. In the first case, the cells spread and adhere strongly. On the multilayer, however, they remain round and did not engage many adhesion sites. Scanning microscopy of platelets demonstrate similar differences in the cell shape when they adhere to the "naked" fibrin gel or the gel coated with soluble fibrinogen (Fig. 7D and 7E) [13, 17].

This phenomenon can be explained by the properties of adhesion receptors, integrins, which provide a physical link between the cytoskeleton and the surrounding matrix. Increasing evidence suggests that integrins participate in these processes by responding and transmitting mechanical stresses across the plasma membrane. Physical forces sensed by integrins are transduced into intracellular chemical signals which, in turn, result in changes of cell behavior. These forces are developed during cell adhesion when integrins engage their ligands in the extracellular matrix. As cells attach, they pull on their surroundings, probing the rigidity of substrates. Therefore, the physical properties of extracellular matrices appear to represent the main signal used by cells to probe adhesiveness of the surface. Rigid surfaces generate strong signals and, as a result, firm adhesion and vice versa, the cells that engage soft matrices are not capable to initiate sufficiently strong signaling and attach weakly. When integrins pull on the fibrinogen monolayer, which can be viewed as a non-extensible rigid substrate because the fibrinogen molecules are directly attached to the hard 


\section{$0.1-1.0 \mu \mathrm{g} / \mathrm{ml}$}

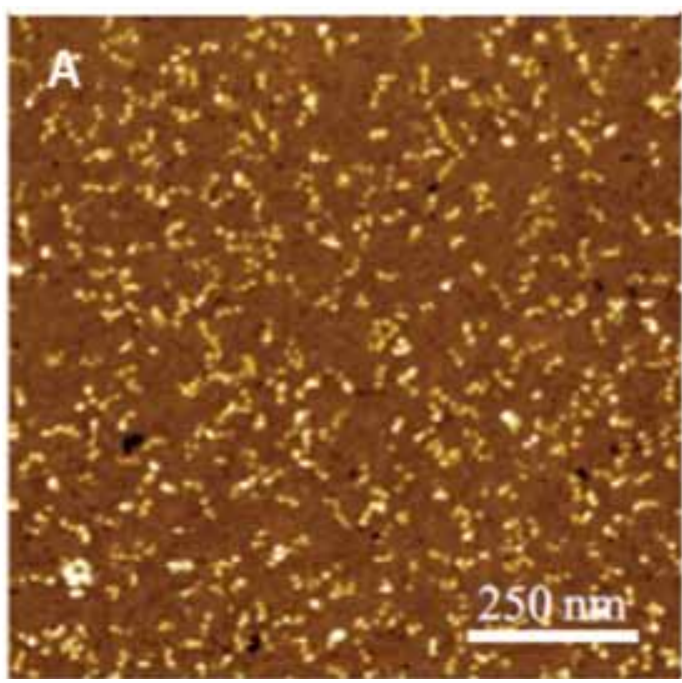

Monolayer
$2-20 \mu \mathrm{g} / \mathrm{ml}$

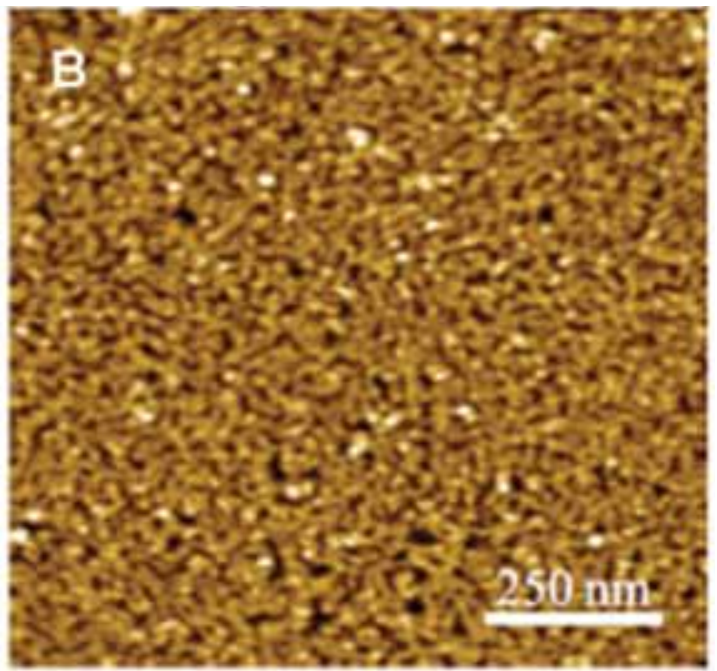

Multilayer

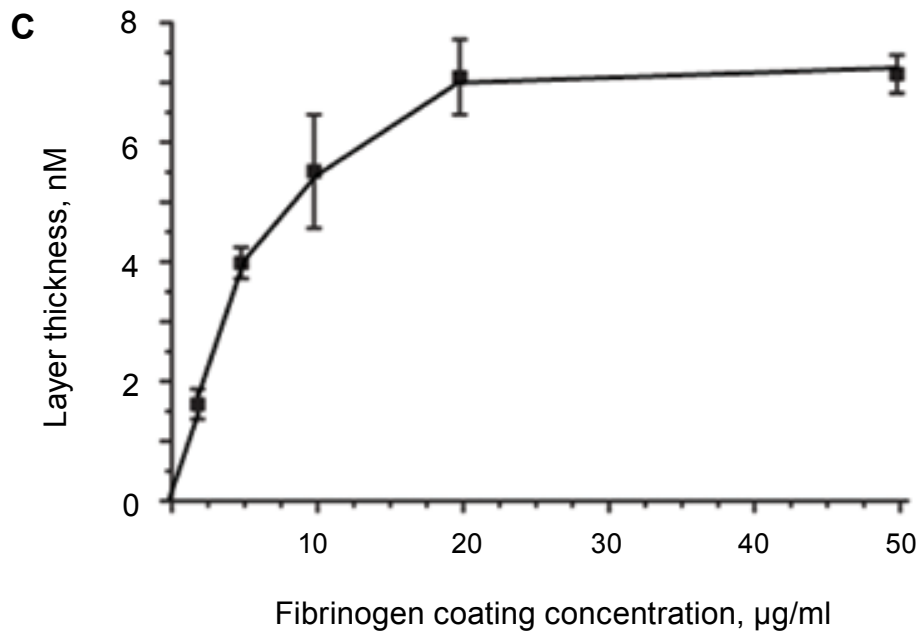

Fig. 6. Atomic force microscopy based imaging of fibrinogen adsorbed on mica at coating concentration $0.1-1.0 \mu \mathrm{g} / \mathrm{ml}$, monolayer (A) and 2-20 $\mathrm{g} / \mathrm{ml}$, multilayer $(\boldsymbol{B})$. Dependence of the thickness of fibrinogen layer on coating concentration $(\boldsymbol{C})$

surface, this substrate does not readily yield and this can generate strong pulling forces sufficient to induce strong signaling leading to cell spreading and strong adhesion. Fibrin can also be viewed as a non-extensible substrate because all the fibers are interconnected. In contrast, when a cell pulls on the fibrinogen multiayer, which is basically an extensible soft matrix, the linkages yield because the layers separate and it prevents force generation and activation of signaling molecules required for cell spreading. Under applied force as it occurs in the circulation, such cells would be easily washed away by flow.

The explanation for this behavior was obtained in the experiments in which we compared the force-distance curves generated on the fibrinogen monolayer or bilayer. One of the parameters that can be extracted from these curves is the adhesion length which is a length when the AFM tip begins to retract from the surface but is still in contact with the substrate. The analyses of adhesion lengths demonstrated that while the fibrinogen monolayer is virtually non-extensible $(0.1 \mathrm{~nm})$ the bilayer can be extended to $3.5 \mathrm{nM}$, suggesting that the molecules held by weak interactions in two layers can be separated. Thus, a simple transition from the monolayer to bilayer initiates a sharp decrease in adhesion forces. Hence, the fibrinogen bilayer represents a minimal structural unit responsible for the formation of nonadhesive fibrino- 

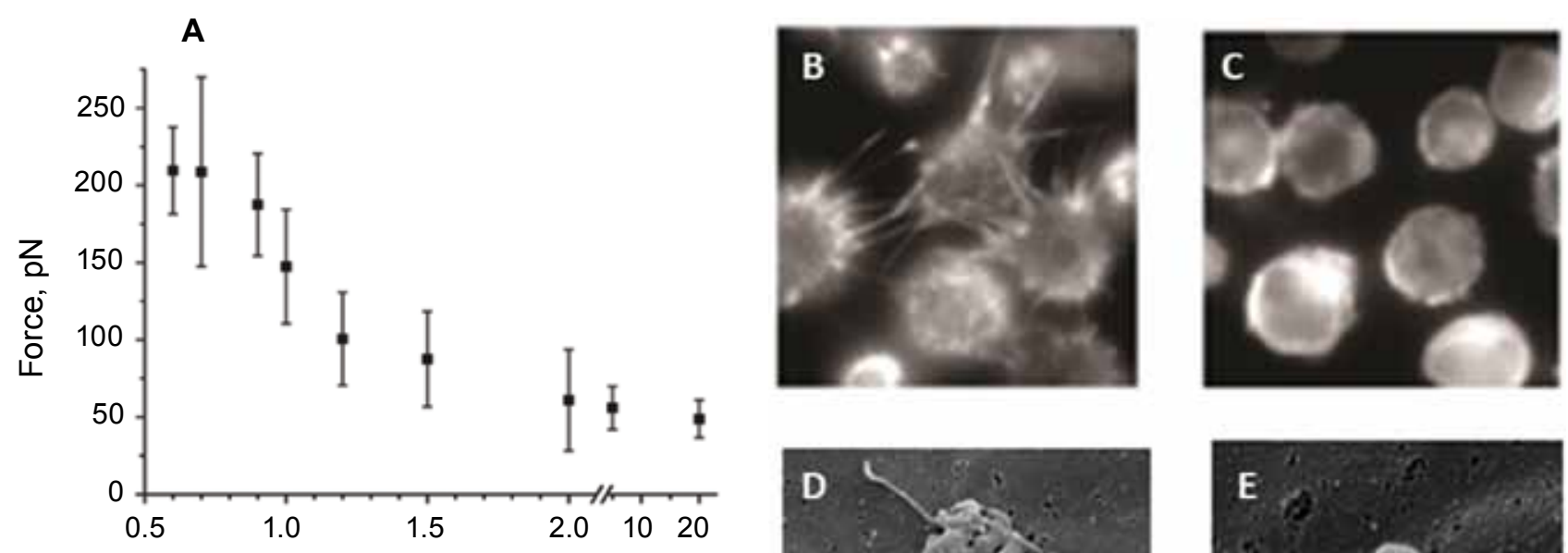

Fibrinogen concentration, $\mu \mathrm{g} / \mathrm{ml}$
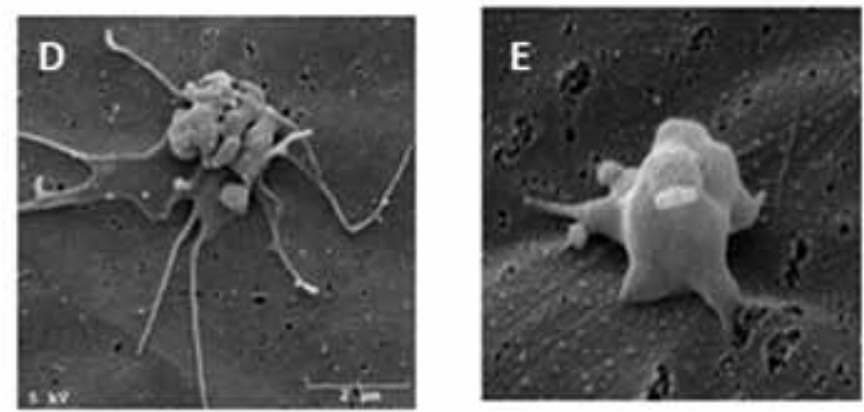

Fig. 7. Dependence of adhesion forces developed between the AFM tip and concentration of coated fibrinogen (A). Visual microscopy of adherent monocytic cells that spread on monolayer of fibrinogen (B) and stay round on the non-adherent surface of the multilayer $(\boldsymbol{C})$. Scanning electron microscopy of adherent spread platelets (D) and non-adherent round cells $(\boldsymbol{E})$ on mono- and multilayer correspondingly

gen matrix. Since the concentration of fibrinogen in the circulation is high it apparently is always deposited as a multilayer. Therefore, the second parameter which is useful in the characterization of the physical properties of the fibrinogen matrices is the maximal interaction length. As the AFM tip retracts from the surface, it pulls the fibrinogen matrix producing multiple rupture events until it finally loses the contact with the matrix. The point where the AFM tip loses the contact with the matrix is defined as the maximal interaction length. The interaction length for the fibrinogen multilayer was determined to be about $60 \mathrm{~nm}$, i.e. the fibrinogen matrix that is deposited as a 7-nm layer can be extended up to 8-fold of its initial height under the applied tensile force. This remarkable property of the multilayer fibrinogen should certainly impact integrin-mediated cell adhesion.

Indeed, the data of molecular force spectroscopy are supported by experiments using single cell force microscopy [15]. In these experiments, a single cell is attached to a tipless AFM cantilever and the optical setup allows for constant monitoring of the cell during each approach-retraction cycle. In our experiments, we used cultured monocytic cells or cells transfected with leukocyte and platelet integrins. The surface of mica is coated with different concentrations of fibrinogen to obtain a monolayer or a multilayer. The cell is brought in contact with the fibrinogen matrix and then detached (Fig. 8). The maximal forces required to detach a cell from a substrate are again the highest when a cell is attached to the fibrinogen monolayer whereas the multilayer develops low adhesion forces with cells. Thus, the combined AFM-based strategy not only confirmed our initial hypothesis but provided unique insights into the mechanisms underlying the construction of the new nanoscale biological material and origin of its potent antiadhesive properties. In our most recent study, we showed that the flexible $\alpha \mathrm{C}$ regions of the fibrinogen molecules grasp each other during the multilayer construction providing thus the molecular basis for its self-assembly [17].

Dependence of cell adhesion on the substrate rigidity prompted us to explore other mechanisms that potentially could prevent cell accumulation at the site of injury. Another plasma protein, plasminogen, interacts with fibrin, is present in plasma at a relatively high concentration and could potentially modify the surface of fibrin clots. Furthermore, affinity of plasminogen for fibrin increases when the surface of a clot is "nicked" with plasmin, resulting in the generation of new binding sites and strong superficial accumulation of plasminogen. In addition, various cells, including leukocytes and 
A

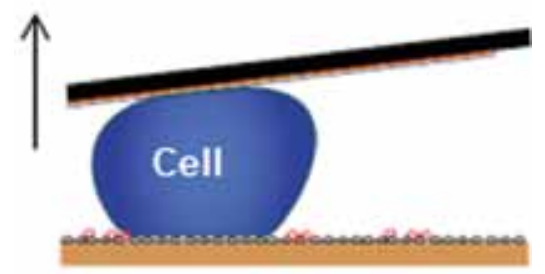

B

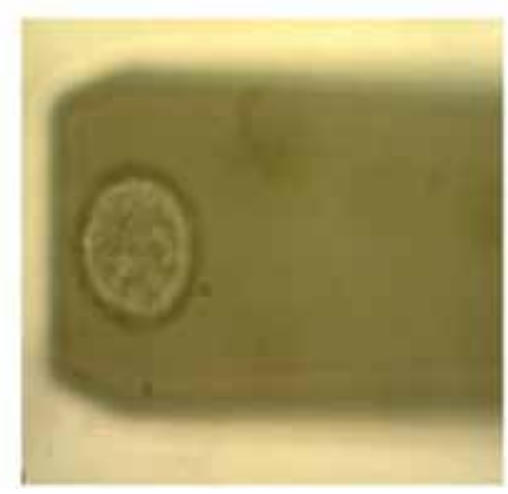

Bottom view
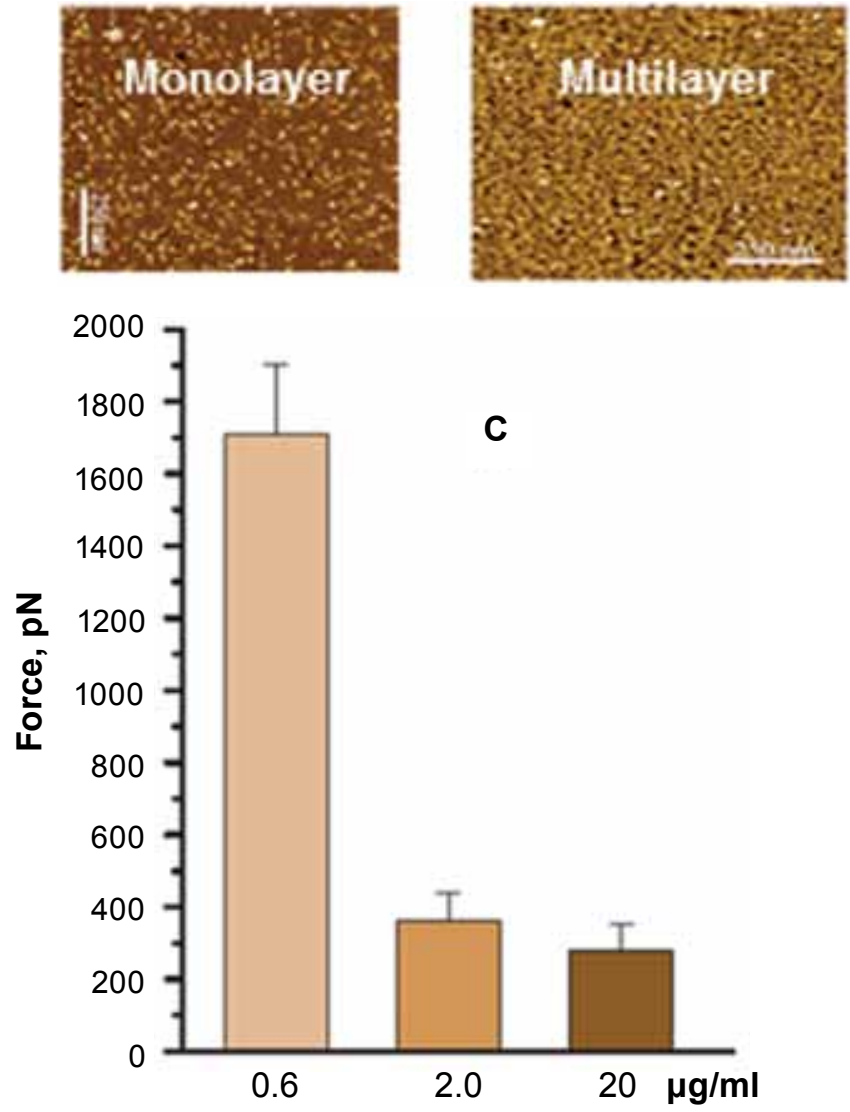

Fig. 8. Diagram of single cell force microscopy experiment: monocytic cell is covalently bound to cantilever and attached to fibrinogen substrate (A); bottom view (B); dependence of detachment force on the structure of fibrinogen coating $(\boldsymbol{C})$

platelets, can assemble and activate plasminogen on their surface. Similar to fibrinogen, plasminogen accumulates in a thin superficial layer of fibrin; as a consequence, fibrin lysis is restricted to a very narrow zone from the clot surface [18]. Therefore, it was reasonable to assume that when blood cells contact a clot, they activate fibrin- or cell-bound plasminogen, resulting in lysis of the superficial fibrin layer, its fragmentation and destabilization of the surface. Hence, such plasminogen shell could potentially influence cell adhesion.

In a series of experiments, we showed that binding of plasminogen to fibrin inhibits cell adhesion and that the conversion by leukocytes and platelets of fibrin-bound plasminogen into plasmin is the mechanism responsible for this antiadhesive effect [14, 19]. Furthermore, plasminogen exerts the antiadhesive effect not only when it binds to the surface of fibrin clots but when it has been added to cells (Fig. 9). Since many cells, including U937 that we used in our experiments, assemble the components of plasminogen activation system and the receptor for plasminogen activator $\mathrm{UPA}$, the antiadhesive effect arises from the plasmin activity generated by cells. Indeed, the addition of PPACK (the inhibitor of serine proteases) to cell suspension completely restores adhesion. In addition, tranexamic acid, which is known to interact with lysine-binding sites of plasminogen and prevents its binding to U937 cells, almost completely abolished the inhibitory effect of plasminogen.

When fibrin gels were first treated with plasminogen and then washed to remove non-bound plasminogen, inhibition of adhesion was $\sim 90 \%$ as compared with non-treated gels. Antiadhesive effect of plasminogen is concentration-dependent, with an $\mathrm{IC}_{50} 0.5 \mu \mathrm{M}$ which corresponds to the range of $K_{\mathrm{d}}$ values $(0.3-1.2 \mu \mathrm{M})$ previously reported for the interaction of plasminogen with fibrin clots or with fibrin immobilized on plastic. Thus, in both systems, when present in the solution or adsorbed on the fibrin surface, plasminogen is capable of blocking cell adhesion due to its conversion to plasmin. It is important to note that in the latter case, activation of plasminogen takes place at the interface between fibrin and adherent cells. 


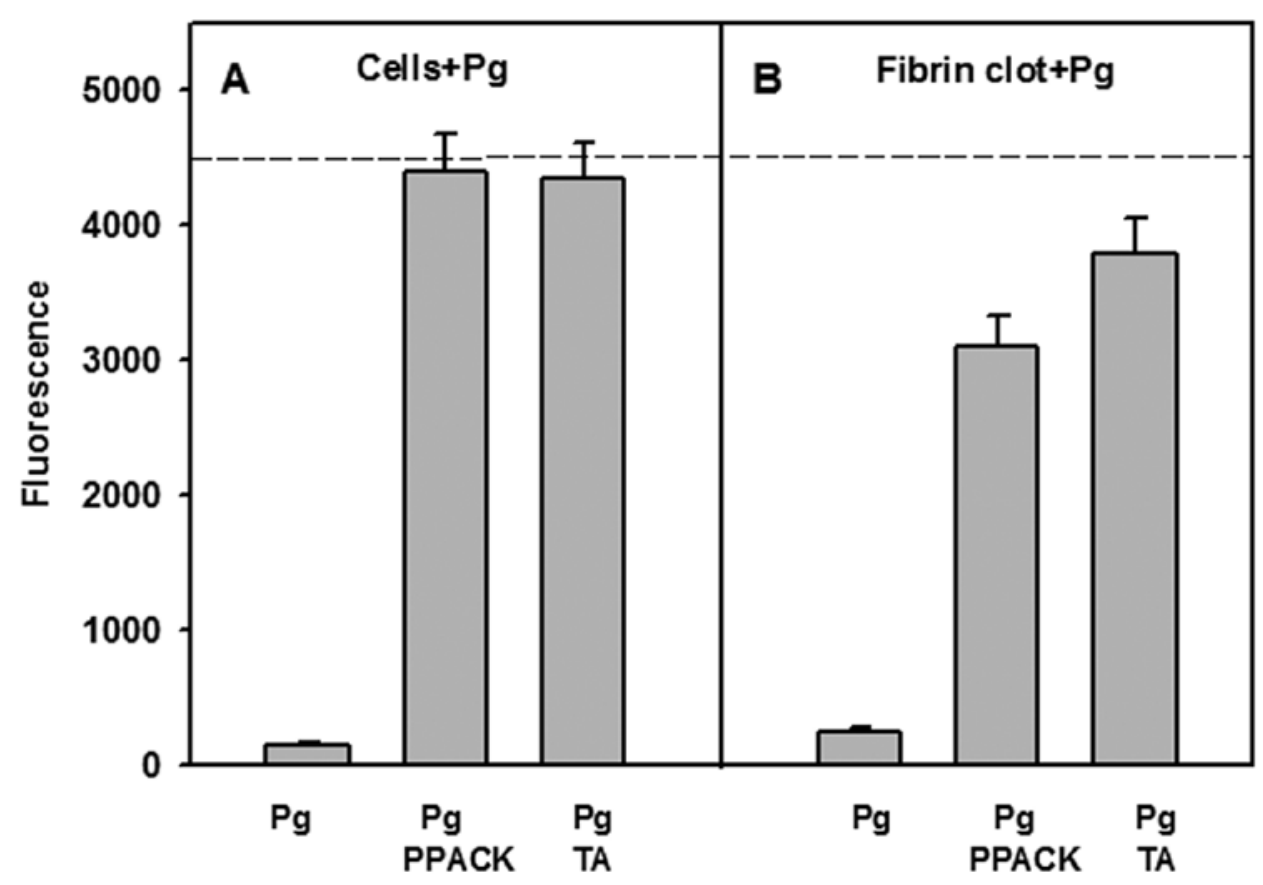

Fig. 9. Effect of plasminogen on adhesion of monocytic cells to fibrin clots. (A) - Cell adhesion when plasminogen was adsorbed on cells and added to fibrin with or without PPACK or tranexamic acid; (B) - Cell adhesion when plasminogen was adsorbed on the fibrin clot in the presence or in the absence of PPACK or tranexamic acid. A dotted line shows control cell adhesion in the absence of plasminogen

In addition to leukocytes, platelets adhere to fibrin via an integrin-dependent mechanism and assemble the components of the plasminogen system, including plasminogen and plasminogen activators $\mathrm{UPA}$ and $\mathrm{tPA}$. Therefore, we have sought to examine whether activation of fibrin-bound plasminogen by platelets can alter their adhesion in the same way as we observed for leukocytes. However, coating of the fibrin gel with plasminogen did not decrease platelet adhesion (Fig. 10A). This was in marked contrast to U937 cells, whose adhesion was abolished by this procedure (Fig. 10B). To understand the difference between adhesion of platelets and that of U937 cells, we measured plasmin activity generated during adhesion of these cells to plasminogen-treated fibrin. Whereas plasmin was generated by U937 cells, no activity was detected with platelets isolated from the platelet-rich plasma. However, the addition of tPA to platelet suspension resulted in the generation of plasmin and inhibition of platelet adhesion to plasminogen-coated fibrin (Fig. 10). Also, in initial experiments, we verified that resting monocytes isolated from peripheral blood did not activate plasminogen and adhere to fibrin gel strongly with or without adsorbed plasminogen. But when suspension of monocytes was pre-incubated with tPA, the loss of monocyte adhesion coincided with the production of plasmin. These results indicate that monocytes and platelets are capable of activation fibrin-bound plasminogen to plasmin in the presence of plasminogen activators the concentration of which rises during vascular injury and thrombus formation.

To demonstrate the effect of plasminogen under permanent shear forces, a situation more relevant to physiologic conditions, we used a flow chamber consisting of a capillary performed within the fibrin gel. Suspensions of U937 cells containing plasminogen were perfused at a flow rate between 25 and $350 \mathrm{sec}^{-1}$. After perfusion, the tubes were flushed with the buffer to remove non-adherent cells. As shown in Fig. 11, in the presence of plasminogen, adhesion is markedly reduced. In fact, fibrin gel perfused with plasminogen retained only few cells.

The above experiments showed that cell attachment to fibrin bound plasminogen causes rapid generation of plasmin, which degrades the surface of fibrin clots rendering them non-adhesive. Remarkably, the surfaces remains non-sticky for the second round of adhesion of U937 cells, even in the presence of PPACK or tranexamic acid. Moreover, platelets which do not generate plasmin in the absence tPA, also do not adhere to the "postadhesion" gels. These results strongly indicate that during the second round of adhesion, plasmin per 


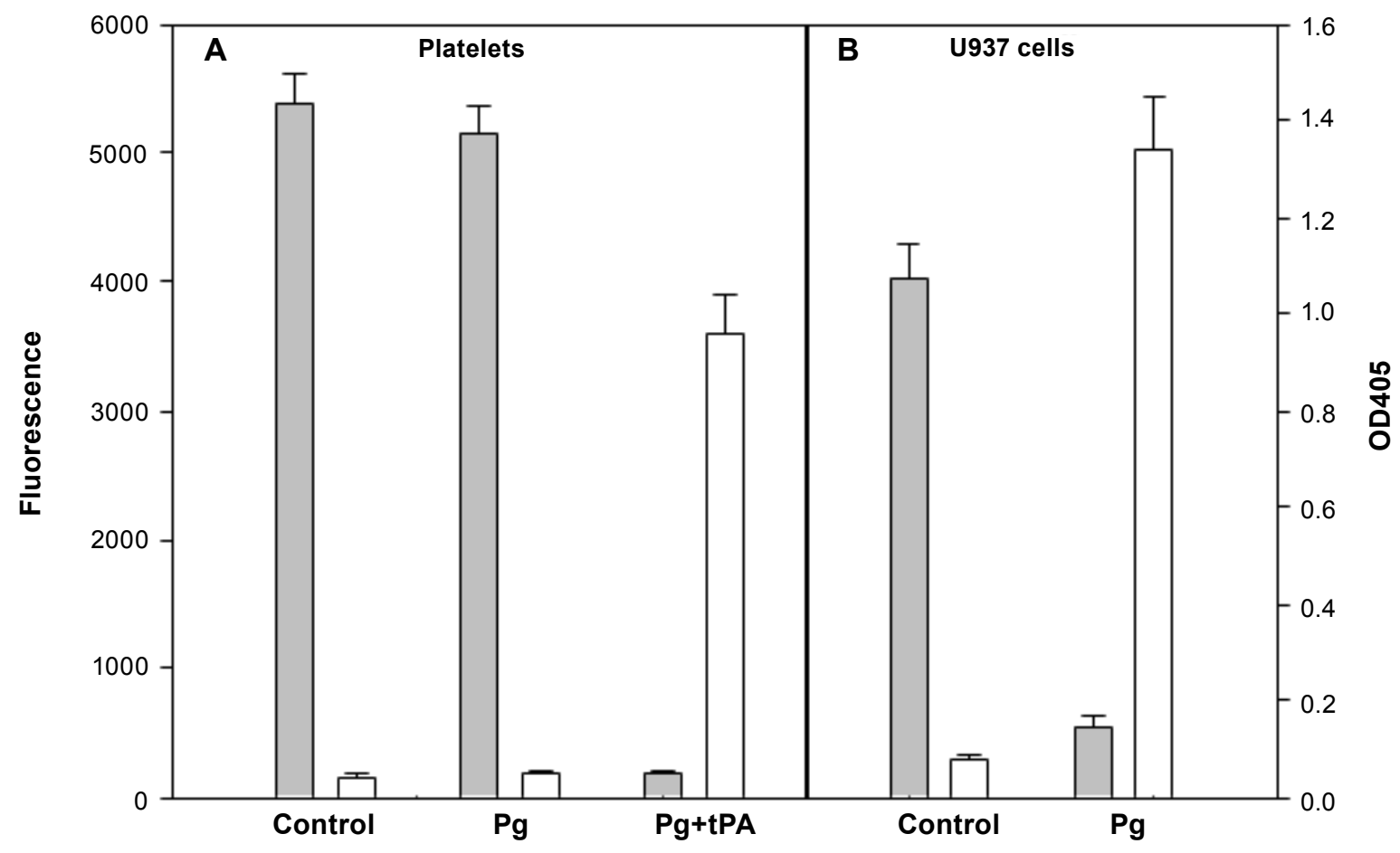

Fig. 10. Relationship between adhesion of platelets (A) and monocytic cells (B) to plasminogen-coated fibrin gel and their ability to activate plasminogen. Grey bars show the fluorescence of adherent cells (left ordinate). Clear bars show (right ordinate) plasmin activity of platelets and monocytic cells incubated with or without plasminogen

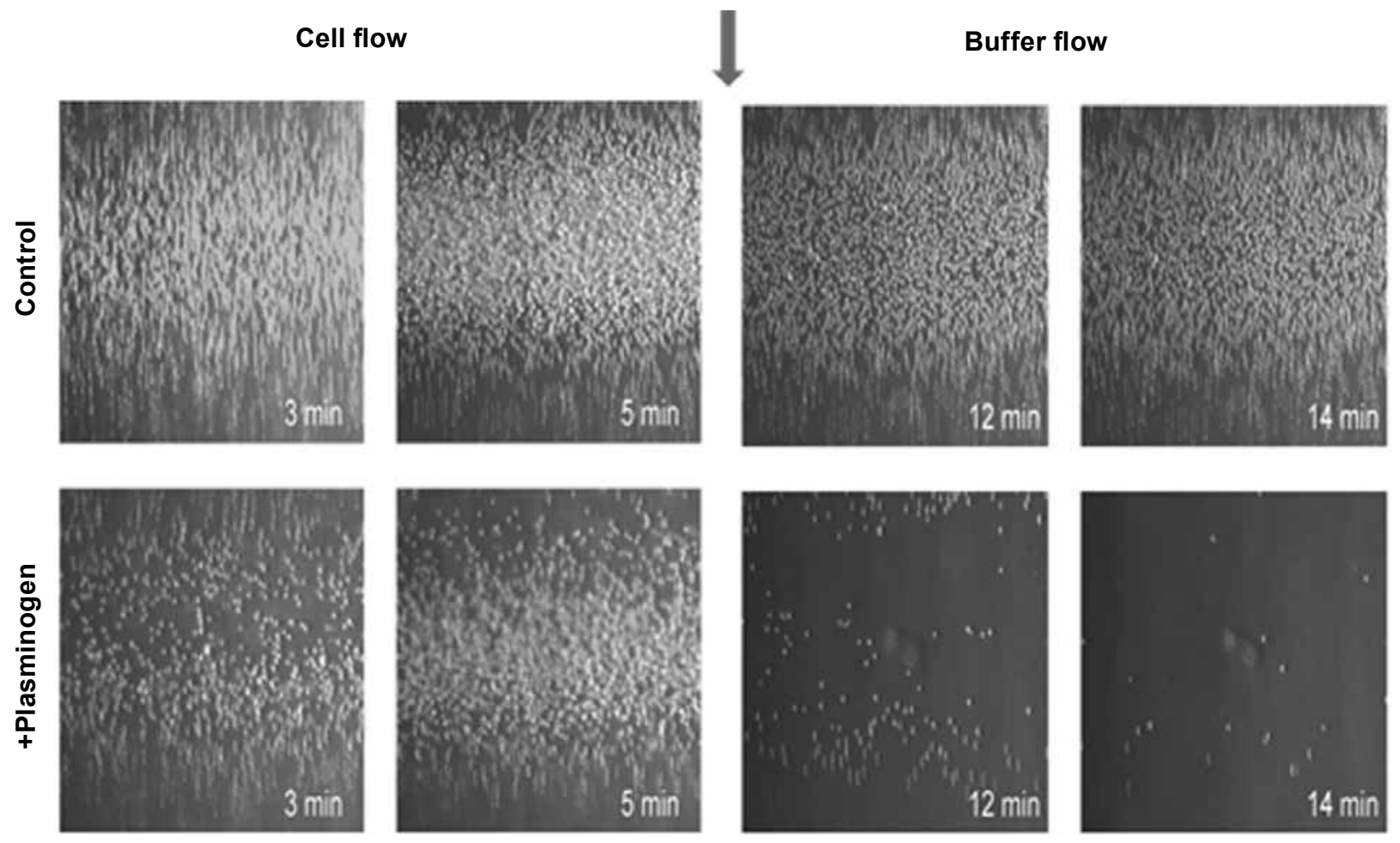

Fig. 11. Effect of plasminogen on adhesion of monocytic cells to fibrin gel under flow condition. The cells were suspended in a buffer with or without (control) plasminogen and perfused through the fibrin gel containing the inner capillary at a flow rate $0.1 \mathrm{ml} / \mathrm{min}$ for $5 \mathrm{~min}$. After this time, the capillary were flushed for additional 12-14 min to remove non-adherent cells. Adherent cells were viewed in microscope at 10x objective 
se is not responsible for the antiadhesive effect. Also, plasmin-mediated cleavage of cell surface integrins does not contribute to the defective cell adhesion. Therefore, the structural alteration of the surface of fibrin produced by plasmin generated by cells during the first round of adhesion is responsible for the inability of clots to support subsequent cell adhesion.

To assess the extent of proteolysis, we determined the amount of fibrin cleaved by generated plasmin. The amount of digested fibrin was estimated by measuring radioactivity released in the solution from gels prepared from ${ }^{125}$ I-labeled fibrinogen after adhesion of U937 cells. It was found that only approximately $0.2 \%$ of fibrin is released from the gel as a result from proteolysis by adherent cells. Thus, plasmin generated by adherent cells appears to produce only minor decomposition of the surface. When such "postadhesive" gels were treated with SDS to remove loosely bound fibrin fragments, the adhesiveness of fibrin clot was restored.

Since both fibrinogen and plasminogen exert potent effect, we examined the interplay between two antiadhesive systems, non-proteolytic fibrinogen-dependent and proteolytic plasminogen-dependent, operating at the same surface of fibrin clot. When fibrin clots are exposed to fibrinogen and plasminogen simultaneously, as it would occur in the circulation, the deposition of fibrinogen on the surface of a clot prevents activation of fibrinbound plasminogen by transiently adherent cells. The precise mechanism by which the simultaneous adsorption of fibrinogen and plasminogen abolishes activation of plasminogen by cells will require further study. However, the simplest interpretation of the observed phenomenon is that the fibrinogen due to its abundance in the circulation produces a matrix which masks the surface-bound plasminogen and precludes its physical contact with cells.

The above experiments show that two fibrinbinding proteins, plasminogen and fibrinogen, strongly reduce adhesion of leukocytes and platelets to fibrin clots, highlighting a possible role for these plasma proteins in surface-mediated control of thrombus growth and stability. In particular, adsorption of fibrinogen on fibrin clots renders their surfaces non-adhesive, while the conversion of surface-bound plasminogen to plasmin by transiently adherent blood cells results in degradation of a superficial fibrin layer, leading to cell detachment in flow. Although the mechanism whereby these proteins exert their antiadhesive effects-proteolytic and non-proteolytic- seems different, the outcome is the same: the formation of mechanically instable surface that does not allow firm cell attachment (Fig. 12).

The existence of two potent antiadhesive mechanisms, fibrinogen- and plasminogen-dependent, raises a question of their potential contribution to the nonadhesive properties of the fibrin clot surface. Because of the clear superiority of the fibrinogen-dependent system, it is uncertain under which circumstances the plasminogen-dependent system may play a significant role. One of the possibilities is the heterogeneity of the clot surface. Recent studies using a novel technique that allowed the imaging of the thrombi developed in large vessels demonstrated that the surface of clots displayed variable spatial intensities of the platelet-, fibrin- and fibrinogen-specific fluorophores, indicating a non-uniform coverage of clots with fibrinogen [3]. Therefore, plasminogen and fibrinogen may accumulate at different regions of the clot. Another possibility is that the contribution of the two antiadhesive systems may be altered in pathological conditions. Further studies of the distribution of fibrinogen and plasminogen on the surface of clots in vivo and in model systems in vitro may help to define the localization and roles of the two antiadhesive systems.

The surface-mediated control of thrombus growth and stability is a new concept. Although the fact that the surfaces of stable hemostatic thrombi are covered with fibrin has been long known, a paradox as to why fibrin, a highly adhesive substrate for platelets and leukocytes in vitro, does not effectively support adhesion of these cells in circulation has not been addressed. We propose that the reason for the loss of reactivity of fibrin clots for platelets and leukocytes is the ability of fibrin to bind both fibrinogen and plasminogen resulting in the assembly of a potent antiadhesive system that guards clots from excessive cell accumulation. This protective mechanism may fulfill a dual purpose. First, it will prevent the accumulation of platelets, thereby halting the overall process of thrombus propagation. Second, it will prevent the recruitment of leukocytes whose premature adhesion with a concurrent release of proteolytic enzymes may compromise the thrombus stability essential for early hemostasis. The efficiency of both fibrinogen- and plasminogen-dependent processes observed in vitro in conjunction with supporting evidence from in vivo studies suggests their physiological relevance. Thus, surface-mediated control of thrombus growth and stability may represent a previously unrecognized aspect of hemostasis. 
$\boldsymbol{A}$

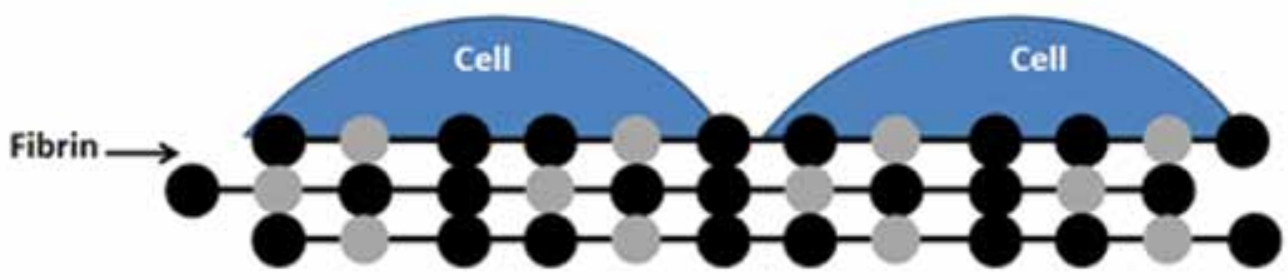

B

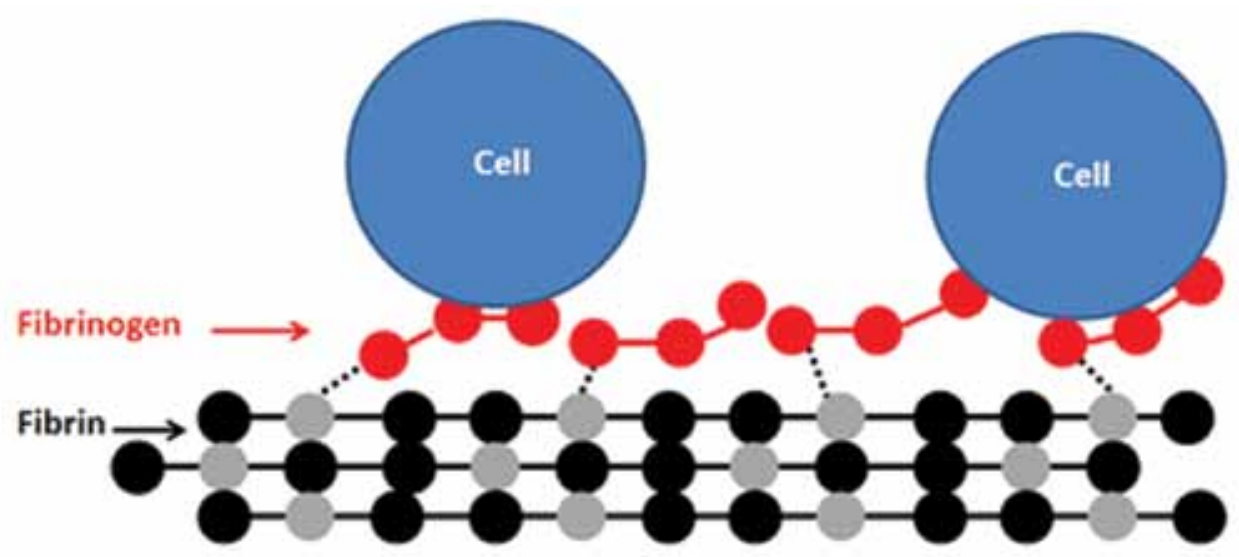

C
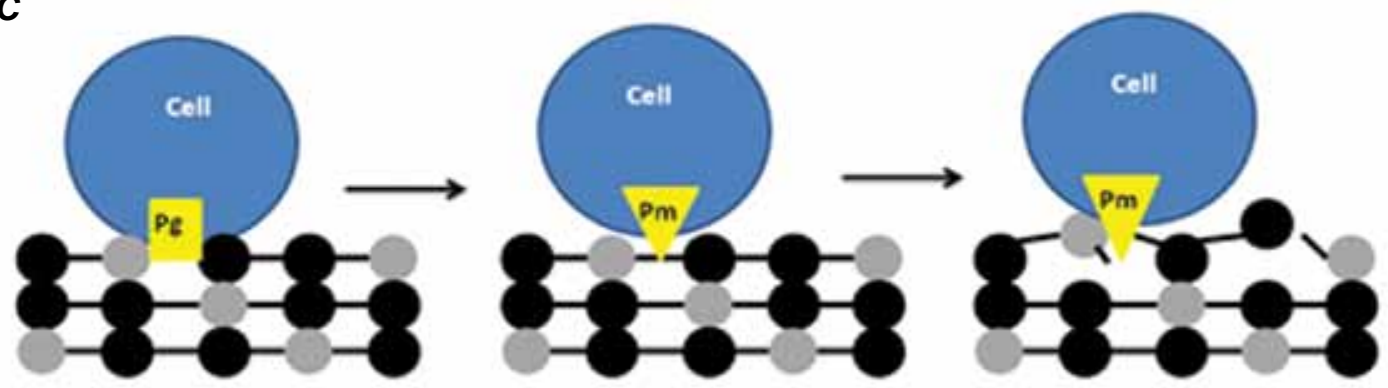

Fig. 12. Model of the mechanisms preventing growth of thrombus in the site of injury. (A, B) Plasma fibrinogen interacts with the surface of fibrin clot, forming a layer consisting of loosely bound molecules. This results in the formation of a "feeble" adhesive substrate. Flowing cells can engage either the solid fibrin matrix followed by spreading and firm adhesion (A), whereas cells that engage loosely bound molecules in the fibrinogen layer slip of, not being able to resist the shearing force of the flow $(\boldsymbol{B}) .(\boldsymbol{C})$ Activation of plasminogen on the surface of fibrin clot by plasminogen activation system results in the generation of plasmin which degrades the superficial fibrin layer. Degraded fibrin molecules are not able to hold cells under flow

\section{НОВЫЙ МЕХАНИЗМ, КОНТРОЛИРУЮЩИЙ РОСТ ГЕМОСТАТИЧЕСКОГО ТРОМБА}

\section{В. К. Лишко, И. С. Ермоленко,}

Н. П. Подольникова, Т. П. Угарова

Государственный университет Аризоны, США, Школа наук о жизни

Существующее представление о механизмах коагуляционного каскада не дает ответа на принципиальный вопрос: почему развитие тромба, образующегося при механическом повреждении сосуда, внезапно прекращается, в отличие от патологического тромба. В настоя- щей статье представлены результаты цикла работ, которые дают ответ на этот вопрос. Мы показываем, что на поверхности фибринового сгустка образуется тонкий метастабильный слой фибриногена, который не способен поддержать адгезию клеток в кровотоке. Тромбоциты и лейкоциты, клетки обладающие адгезивными интегринами, не могут закрепиться на сгустке, смываются потоком крови и образование тромба, таким образом, останавливается. Клетки, которые вопреки фибриногеновому щиту все-таки достигли устойчивой поверхности фибрина, используют дополнительный механизм - способность активировать плазминоген, связанный с клеточной поверхностью или 
с самим фибрином. Плазмин, образующийся в интерфейсе между клеткой и поверхностью сгустка, локально расщепляет фибрин. Фрагментированная поверхность сгустка становится неустойчивой, неадгезивной и поэтому нетромбогенной. Таким образом, остановка роста гемостатического тромба обеспечивается двумя механизмами, фибриноген- и плазминогензависимыми, основанными на едином принципе - создание механическиски нестабильной неадгезивной поверхности.

К л ю чевы е с лова: тромбообразование, фибриноген, фибрин, плазминоген, плазмин, активирование плазминогена, механическое повреждение сосудов.

\section{НОВИЙ МЕХАНІЗМ, КОНТРОЛЮЮЧИЙ РІСТ ГЕМОСТАТИЧНОГО ТРОМБУ}

\author{
В. К. Лішко, І. С. Срмоленко, \\ Н. П. Подольнікова, Т. П. Угарова \\ Державний університерт Арізони, \\ США, Школа наук про життя
}

Існуюче уявлення про механізми коагуляційного каскаду не дає відповіді на принципове питання: чому розвиток тромбу, що утворюється під час механічного пошкодження судини, раптово припиняється, на відміну від патологічного тромбу. У цій статті представлено результати циклу робіт, які дають відповідь на це питання. Ми показуємо, що на поверхні фібринового згустку утворюється тонкий метастабільний шар фібриногену, який не здатний підтримати адгезію клітин у кровотоці. Внаслідок цього тромбоцити i лейкоцити, клітини, які мають адгезивні інтегрини, не можуть закріпитися на згустку, змиваються потоком крові і розвиток тромбу, таким чином, зупиняється. Клітини, які всупереч фібриногеновому щиту таки досягли стійкої поверхні фібрину, використовують додатковий механізм - здатність активувати плазміноген, пов'язаний із клітинною поверхнею або із самим фібрином. Плазмін, що утворюється в інтерфейсі між клітиною i поверхнею згустку, локально розщеплює фібрин. Фрагментована поверхня згустку стає нестійкою, неадгезивною і тому нетромбогенною. Таким чином, зупинка росту гемостатичного тромбу забезпечується двома механізмами: фібриноген- і плазміногензалежними, які засновано за одним принципом - створення механічно нестабільної неадгезивної поверхні.
Кл юч ов і слова: тромбоутворення, фібриноген, фібрин, плазміноген, плазмін, активування плазміногену, механічне пошкодження судин.

1. Falati S., Cross P., Merrill-Skoloff G. et al. // Nat. Med. - 2002. - 8. - P. 1175-1181.

2. Kamocka M. M., Mu J., Chen N. et al. // J. Biomed. Optics. - 2010. - 15. - P. 0160201-016020-7.

3. Cooley B. C. // Arterioscler.Thromb. Vasc. Biol. - 2011. - 31. - P. 1351-1356.

4. van Aken P. J., Emeis J. J. // Artery. - 1982. 11. - P. 156-173.

5. van Ryn J., Lorenz M., Merk H. et al. // Thromb. Haemost. - 2003. - 90. - P. 1179-1186.

6. Groves H. M., Kinlough-Rathbone R. L., Richardson M. et al. // Lab. Invest. - 1982. 46. - P. 605-612.

7. McGuiness C. L., Humphries J., Waltham M. et al. // Thromb.Haemost. - 2001. - 85. P. $1018-1024$.

8. Lishko V. K., Burke T., Ugarova T. P. // Blood. - 2007. - 109. - P. 1541-1549.

9. Schielen W. J. G., Voskuilen M., Tesser G. I., Nieuwenhuizen $W$. // Proc. Natl. Acad. Sci. USA. - 1989. - 86. - P. 8951-8954.

10. Zamarron C., Ginsberg M. H., Plow E. F. // Thromb. Haemost. - 1990. - 64. - P. 41-46.

11. Ugarova T. P., Budzynski A. Z., Shattil S. J. et al. // J. Biol. Chem. - 1993. - 268. P. 21080-21087.

12. Lishko V. K., Kudryk B., Yakubenko V. P. et al. // Biochemistry. - 2002. - 41. - P. 1294212951.

13. Podolnikova N. P., Yermolenko I. S., Fuhrmann A. et al. // Biochemistry. - 2010. 49. - P. 68-77.

14. Lisko V. K., Yermolenko I. S., Owaynat H., Ugarova T. P. // J. Thromb. Haemost. 2012. - 10. - P. 1081-1090.

15. Yermolenko I. S., Fuhrmann A., Magonov S. N. et al. // Langmuir. - 2010. - 26. - P. 1726917277.

16. Yermolenko I. S., Lishko V. K., Ugarova T. P., Magonov S. N. // Biomacromolecules. - 2013. 12. - P. 370-379.

17. Yermolenko I. S., Gorkun O. V., Fuhrmann A. et al. // J. Biol. Chem. - 2012. - 287. P. 141979-141990.

18. Sakharov D. V., Rijken D. C. // Circulation. 1995. - 92. - P. 1883-1890.

19. Lishko V. K., Yermolenko I. S., Ugarova T. P. // J. Thromb. Haemost. - 2010. - 8. - P. 799-807. 